\title{
TINGKAT PARTISIPASI MASYARAKAT DALAM PENGEMBANGAN EKOWISATA KERUJUK BERBASIS MASYARAKAT DI DESA MENGGALA KECAMATAN PEMENANG KABUPATEN LOMBOK UTARA
}

\section{LEVEL OF COMMUNITY PARTICIPATION IN THE DEVELOPMENT \\ OF COMMUNITY BASED KERUJUK ECOTOURISM IN MENGALA VILLAGE PEMENANG DISTRICT NORTH LOMBOK REGENCY}

\author{
Amalia Khairunnisa $^{1 *}$, Lalu Wirasapta Karyadi ${ }^{2}$, Rosiady Husaenie Sayuti $^{2}$ \\ ${ }^{1 *}$ Program Studi Agribisnis, Universitas Mataram, Mataram, Indonesia \\ ${ }^{2}$ Program Studi Sosiologi, Universitas Mataram, Mataram, Indonesia \\ *Email Penulis korespondensi: amaliakhairunnisa1998@gmail.com
}

\begin{abstract}
ABSTRAK
Penelitian ini bertujuan untuk : (1) menganalisis tingkat partisipasi masyarakat dalam upaya pengembangan ekowisata kerujuk; (2) menganalisis faktor-faktor apa yang berhubungan dengan tingkat partisipasi masyarakat dalam upaya pengembangan ekowisata kerujuk; (3) menganalisis strategi apa yang dapat diterapkan untuk dapat meningkatkan partisipasi masyarakat dalam upaya pengembangan ekowisata kerujuk. Metode penelitian yang digunakan dalam penelitian ini adalah metode deskriptif. Penelitian dilaksanakan di Dusun Kerujuk Desa Mengala yang dipilih secara purposive sampling dengan pertimbangan bahwa dusun tersebut mempunyai program ekowisata yang melibatkan masyarakat. Penentuan jumlah responden ditetapkan secara proportionate stratified random sampling dengan menggunakan rumus Slovin dan ditetapkan jumlah responden sebanyak 43 responden. Data yang terkumpul kemudian dianalisis dengan menggunakan system skoring, analisis uji korelasi rank spearman dan analisis SWOT. Hasil penelitian menunjukkan bahwa tingkat partisipasi masyarakat termasuk di kategori rendah karena keterlibatan masyarakat masih kurang di seluruh tahapan kegiatan yang dilaksanakan dalam upaya pengembangan ekowisata kerujuk. Faktor-faktor yang berhubungan dengan tingkat partisipasi masyarakat adalah pendidikan non-formal ( $s k i l l$ ), pendapatan, lama tinggal dan umur. Strategi yang dapat diterapkan dalam upaya meningkatkan partisipasi masyarakat adalah strategi WO atau weakness-opportunity, dimana upaya-upaya kerjasama dengan pemerintah atau lembaga pendidikan untuk melakukan pembinaan meningkatkan kualitas sumberdaya manusia untuk lebih mandiri dalam mengelola ekowisata kerujuk yang kreatif dan inovatif.
\end{abstract}

Kata kunci : Berbasis masyarakat, Ekowisata Kerujuk, Partisipasi, Pengembangan

\section{ABSTRACT}

This study aims to: (1) analyze the level of community participation in the development of ecotourism referrals; (2) analyze what factors are related to the level of community participation in the development of referred ecotourism; (3) analyze what strategies can be applied to increase community participation in the development of ecotourism referrals. The research method used in this research is descriptive method. The research was conducted in Kerujuk Hamlet, Mengala Village which was selected by purposive sampling with the consideration that the hamlet has an ecotourism program that involves the community. The determination of the number of respondents was determined by proportionate stratified random sampling using the Slovin formula and the number of respondents was determined to be 43 respondents. The collected data was then analyzed using a scoring system, Spearman rank correlation test analysis and SWOT analysis. The results showed that the level of community participation was included in the low category because community involvement was still lacking in all stages of activities carried out in an effort to develop ecotourism referrals. Factors related to the level of community participation are nonformal education (skills), income, length of stay and age. The strategy that can be applied in an effort to increase community participation is the WO strategy or weakness-opportunity, where 
cooperative efforts with the government or educational institutions are carried out to improve the quality of human resources to be more independent in managing creative and innovative referral ecotourism.

Keywords: Community based, Kerujuk Ecotourism, Participation, Development

\section{PENDAHULUAN}

Peningkatakan jumlah kunjungan wisatawan di wilayah Nusa Tenggara Barat dari tahun ketahun mengalamai kenaikan yang sangat signifikan (BPS NTB, 2019). Salah satu wilayah yang menjadi daerah tujuan wisata yaitu Kabupaten Lombok Utara dengan wisata tiga gili. Hal tersebut memicu pegiat wisata lainnya untuk membangun daerah tujuan wisata baru yang berkonsep ekowisata. Ekowisata adalah pariwisata berkonsep pada ekologi lingkungan dengan tetap mempertahankan keasrian wilayahnya yang berkelanjutan dan memiliki tujuan untuk membantu perekonomian juga partisipasi masyarakat sehingga manfaatnya mampu dirasakan oleh pemerintah dan masyarakat setempat (Dinas Pariwisata dan Kebudayaan, 2009).

Ekowisata dapat menciptakan peluang kerja bagi masyarakat setempat untuk membangun fasilitas wisata sebagai daya jual yang menjadi sumber pendapatan. Fasilitas ekowisata yang dapat dijadikan sumber pendapatan masyarakat dapat berupa pemandu wisata, membuka penginapan, membuka rumah makan, warung suvenir, penyedia jasa transportasi, dan usaha-usaha lain yang berkaitan dengan kegiatan ekowisata. Dengan demikian kegiatan ekowisata ini dapat memberikan tambahan penghasilan sehingga dapat meningkatkan kesejahteraan masyarakat setempat (Zuhriana, 2013).

Desa Menggala Kecamatan Pemenang Kabupaten Lombok Utara merupakan salah satu desa yang mengembangkan konsep ekowisata yaitu ekowisata kerujuk. Salah satu penerapan konsep ekowisata yang dibangun di Dusun Kerujuk Desa Menggala bertujuan meningkatkan perekonomian masyarakat karena mempunyai pengaruh yang sangat luas terhadap sektor-sektor lainnya. Selain itu, ekowisata ini sangat membutuhkan partisipasi masyarakat dalam mengelola dan mengembangkannya, sehingga dalam perencanaannya ekowisata ini perlu dibentuk dengan konsep ekowisata berbasis masyarakat.

Saat ini partisipasi masyarakat pada ekowisata kerujuk masih urang yang mengakibatkan banyak fasilitas ekowisata yang rusak karena kurangnya perawatan dan pengelolaan yang baik. Kemudian hal tersebut jadi penyebab menurunnya jumlah kunjungan wisatawan, sehingga ekowisata kerujuk berada pada kondisi yang stagnan dan tidak dapat membuka kunjungan wisatawan dalam beberapa waktu. Oleh karena itu tujuan dari penelitian ini yaitu untuk menganalisis tingkat partisipasi masyarakat, menganalisis faktor-faktor apa yang berhubungan dengan tingkat partisipasi masyarakat dan menganalisis strategi apa yang dapat diterapkan untuk dapat meningkatkan partisipasi masyarakat dalam upaya pengembangan ekowisata kerujuk. 


\section{METODE PENELITIAN}

Metode penelitian yang digunakan dalam penelitian ini adalah metode deskriptif. Metode deskriptif yaitu metode yang digunakan untuk meneliti suatu objek atau kondisi pada masa sekarang dengan bertujuan untuk memberikan gambaran secara sistematis, factual dan akurat mengenai fakta-fakta, sifat-sifat serta hubungan antar fenomena yang diselidiki (Nazir, 2014). Jenis data yang digunakan dalam penelitian ini meliputi data kualitatif dan kuantitatif. Data yang digunakan dalam penelitian ini adalah data primer dan data sekunder.

Unit analisis dalam penelitian ini adalah masyarakat Dusun Kerujuk Desa Menggala Kecamatan Pemenang. Penentuan daerah sampel secara purposive sampling atau sengaja sebagai lokasi penelitian dengan pertimbangan bahwa dusun tersebut mempunyai program ekowisata yang melibatkan masyarakat. Penentuan jumlah responden ditetapkan secara proportionate stratified random sampling dengan menggunakan rumus Slovin dan ditetapkan jumlah responden sebanyak 43 responden.

Variabel dan cara pengukuran dalam penelitian ini ada 3, yaitu : (1) tingkat partisipasi masyarakat dengan menggunkan system skoring disetiap variabel dengan menggunakan skala Likert (2) faktor pendorong dan penghambat yang berhubungan dengan tingkat partisipasi masyarakat menggunakan analisis uji korelasi rank spearman (3) strategi untuk meningkatkan partisipasi masyarakat menggunakan analisis SWOT.

Untuk mengetahui tingkat partisipasi masyarakat Dusun Kerujuk pada 4 tahapan, yaitu : (1) tahap perencanaan (2) pelaksanaan (3) pemanfaatan hasil (4) evaluasi memberikan skor disetiap variabel dengan analisis skala likert.

Tabel 1. Skala Likert digunakan untuk mengukur partisipasi masyarakat

\begin{tabular}{llll}
\hline No. & Simbol & Keterangan & Skor \\
\hline 1 & SL & Selalu & 4 \\
2 & SR & Sering & 3 \\
3 & KK & Kadang-kadang & 2 \\
4 & TP & Tidak pernah & 1 \\
\hline
\end{tabular}

Selanjutnya dengan menggunakan interval skor di atas maka ditetapkan kriteria partisipasi sebagai berikut :

$$
\begin{aligned}
& \text { Interval Skor }=\frac{\text { skor maksimum }- \text { skor minimum }}{\text { kategori }} \\
& \text { Interval Skor }=\frac{196-49}{3}=\frac{147}{3}=49
\end{aligned}
$$

Tabel 2. Kriteria partisipasi masyarakat dalam pengembangan ekowisata

\begin{tabular}{ll}
\hline Interval skor & Kategori \\
\hline $49-97$ & Rendah \\
$98-146$ & Sedang \\
$147-196$ & Tinggi \\
\hline \multicolumn{2}{c}{ Untuk mengetahui faktor pendukung dan penghambar yang berhubungan }
\end{tabular}
dengan tingkat partisipasi masyarakat dapat diukur dengan analisis korelasi rank spearman dengan rumus yang digunakan yaitu :

$$
r s=1-\frac{6 \sum d i^{2}}{n\left(n^{2}-1\right)}
$$


Analisis SWOT digunakan untuk menentukan strategi peningkatan partisipasi masyarakat. Data SWOT kuantitatif yang diperoleh dari hasil kuesioner (rating) yang dirincinkan dalam matriks variabel SWOT selanjutnya diolah melalui tiga tahapan, yaitu :

1. Perhitungan bobot dan skor

a. Bobot dari masing-masing faktor internal atau eksternal diperoleh melalui pembagian antara signifikansi bobot dari faktor yang bersangkutan dengan total siginifikansi bobot dari faktor internal atau eksternal.

b. Skor dari masing-masing faktor internal atau eksternal diperoleh melalui perkalian antara nilai bobot dengan nilai rating.

c. Bobot dan skor secara lebih lanjut diolah menggunakan tabel bantu faktor internal dan eksternal sebagaimana yang ada pada tabel $\mathrm{x}$ dan tabel $\mathrm{y}$.

2. Penentuan titik koordinat

a. Titk pada koordinat " $x$ " diperoleh melalui pengurangan total skor strenght dengan total skor weakness.

b. Titk pada koordinat "y" diperoleh melalui pengurangan total skor opportunity dengan total skor threat.

c. Titik koordinat secara lebih lanjut diolah juga menggunakan baris terakhir dari masing-masing tabel bantu faktor internal dan eksternal sebagaimana yang ada pada tabel $\mathrm{x}$ dan tabel $\mathrm{y}$.

3. Tahapan terakhir adalah mencari posisi strategi yang ditujukan oleh titik $(\mathrm{x}, \mathrm{y})$ di dalam kuadran strategi SWOT sebagaimana yang terdapat pada gambar z.

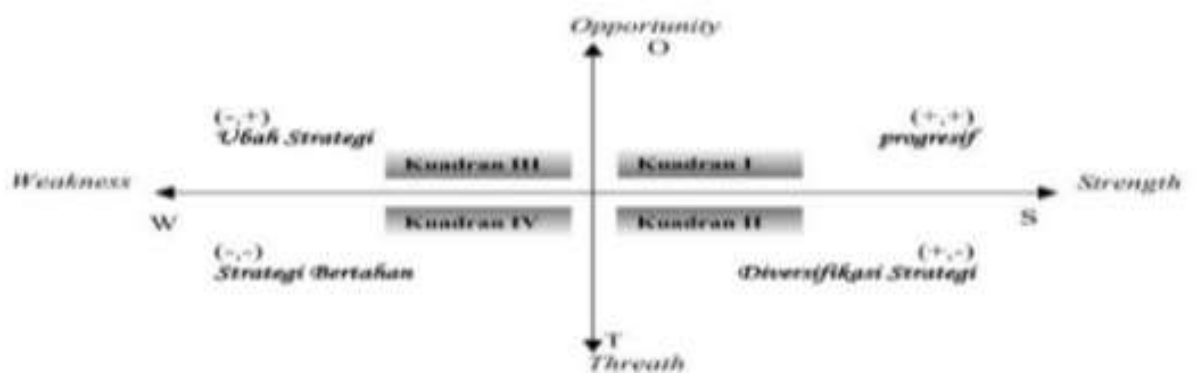

Gambar 1. Kuadran strategi SWOT

\section{HASIL DAN PEMBAHASAN}

\section{Analisis Tingkat Partisipasi Masyarakat Dalam Pengembangan Ekowisata}

Tujuan analisis ini adalah untuk mengetahui tingkat partisipasi masyarakat di setiap tahapan kegiatan partisipasi. Setelah dilakukan penelitian diperoleh hasil keseluruhan tingkat partisipasi masyarakat dalam pengembangan ekowisata kerujuk adalah kategori sedang dengan total skor sebanyak 86.

Tabel 3. Tingkat Partisipasi Masyarakat Dalam Pengembangan Ekowisata

\begin{tabular}{llcl}
\hline No. & Variabel & Skor & Kategori \\
\hline 1. & Perencanaan & 24 & Rendah \\
2. & Pelaksanaan & 44 & Rendah \\
3. & Pemanfaatan Hasil & 11 & Rendah \\
4. & Evaluasi & 7 & Rendah \\
\hline Skor (Gabungan) & 86 & Rendah \\
\hline
\end{tabular}

Sumber : Data Primer diolah (2021) 
Berdasarkan tabel di atas, secara keseluruhan tingkat partispasi masyarakat berada pada kategori tingkat partisipasi rendah. Rendahnya partisipasi masyarakat dalam pengembangan kawasan ekowisata ini diakibatkan rendahnya keterlibatan masyarakat ditahap perencanaan, pelaksanaan, pemanfaatan hasil, dan evaluasi. Hal tersebut dikarenakan sejak awal perencanaan pembangunan ekowisata kerujuk ini bukan merupakan kesadaran masyarakat setempat, melaikan atas usulan dari pemerintah Kabupaten Lombok Utara yang melihat banyaknya potensi wisata yang ada di Dusun Kerujuk Desa Menggala. Menyadari hal tersebut, maka tipologi partisipasi masyarakat Dusun Kerujuk Desa Menggala merupakan partisipasi terdorong atau induced participation.

Rendahnya partisipasi masyarakat dalam mengembangkan kawasan ekowisata kerujuk akibat belum maksimalnya pelibatan masyarakat lokal dalam mengelola potensi Desa. Hal tersebut selaras dengan sebuah penelitian Desa Wisata Genting Kabupaten Semarang yang mengidentifikasi bahwa tingkat partisipasi masyarakat yang rendah disebabkan oleh lemahnya komunikasi dan informasi antar masyarakat desa dalam menerima dan memahami informasi (Manggala, 2014).

Tabel 4. Sebaran Responden Berdasarkan Tingkat Partisipasi Pada Tiap Tahap

\begin{tabular}{|c|c|c|c|c|c|c|c|c|c|}
\hline \multirow{3}{*}{$\mathrm{NO}$} & \multirow{3}{*}{ Jenis Kegiatan } & \multicolumn{6}{|c|}{ Pencapaian Skor Responden } & \multirow{2}{*}{\multicolumn{2}{|c|}{ Total }} \\
\hline & & \multicolumn{2}{|c|}{ Tinggi } & \multicolumn{2}{|c|}{ Sedang } & \multicolumn{2}{|c|}{ Rendah } & & \\
\hline & & $\sum$ & $\%$ & $\sum$ & $\%$ & $\sum$ & $\%$ & $\sum$ & $\%$ \\
\hline \multirow[t]{6}{*}{1} & Perencanaan & & & & & & & & \\
\hline & a. sosialisasi program ekowisata & 11 & 25,58 & 9 & 23,26 & 22 & 51,16 & 43 & 100 \\
\hline & b. Pembentukan kelompok & 20 & 46,51 & 16 & 37,21 & 7 & 16,28 & 43 & 100 \\
\hline & c. Identifikasi masalah & 13 & 30,23 & 1 & 2,32 & 29 & 67,45 & 43 & 100 \\
\hline & d. Penyusunan rencana kegiatan & 25 & 58,13 & 3 & 6,98 & 15 & 34,89 & 43 & 100 \\
\hline & Total & 15 & 34,88 & 10 & 23,26 & 18 & 41,86 & 43 & 100 \\
\hline \multirow[t]{8}{*}{2} & Pelaksanaan & & & & & & & & \\
\hline & a. Pertemuan rutin kelompok & 26 & 60,47 & 7 & 16,27 & 10 & 23,26 & 43 & 100 \\
\hline & b. Pembangunan fasilitas ekowisata & 4 & 9,30 & 6 & 13,95 & 33 & 76,75 & 43 & 100 \\
\hline & c. Pengelolaan dan pemeliharaan fasilitas ekowisata & - & - & 8 & 18,60 & 35 & 81,40 & 43 & 100 \\
\hline & d. Sumbangan materi dan pikiran & 13 & 30.23 & 12 & 27.91 & 18 & 41.86 & 43 & 100 \\
\hline & e. Pelatihan kelompok & 21 & 48,84 & 8 & 18,60 & 14 & 32,56 & 43 & 100 \\
\hline & f. Program kegiatan & 6 & 13,95 & 8 & 18,60 & 29 & 67,45 & 43 & 100 \\
\hline & Total & 4 & 9,30 & 19 & 44,19 & 21 & 48,83 & 43 & 100 \\
\hline \multirow[t]{4}{*}{3} & Pemanfaatan Hasil & & & & & & & & \\
\hline & a. Pemanfaatan sarana dan prasarana & 43 & 100 & - & - & - & - & 43 & 100 \\
\hline & b. Pemanfaatan pendapatan ekowisata & 5 & 11,63 & 3 & 6,98 & 35 & 81,39 & 43 & 100 \\
\hline & Total & 3 & 6,98 & 4 & 9,30 & 36 & 82,72 & 43 & 100 \\
\hline \multirow[t]{3}{*}{4} & Evaluasi & & & & & & & & \\
\hline & a. Evaluasi program ekowisata & 14 & 32,57 & 6 & 13,95 & 23 & 53,48 & 43 & 100 \\
\hline & Total & 14 & 32,56 & 6 & 13,95 & 23 & 53,48 & 43 & 100 \\
\hline \multicolumn{2}{|c|}{ SKOR TINGKAT PARTISIPASI MASYARAKAT } & 5 & 11,63 & 18 & 41,86 & 20 & 46,51 & 43 & 100 \\
\hline
\end{tabular}

Sumber : Data Primer diolah (2021)

\section{Partisipasi Masyarakat Ditahap Perencanaan}

Tahap perencanaan merupakan keterlibatan masyarakat dalam kegiatankegiatan perencanaan terkait perencanaan program ekowisata sesuai dengan potensi yang dimiliki Dusun Kerujuk Desa Menggala. 


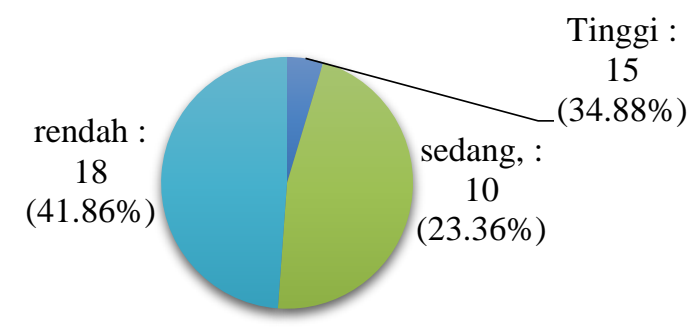

Gambar 2. Jumlah Tingkat Partisipasi Tahap Perencanaan

Gambar 2 di atas menunjukkan bahwa, tingkat partisipasi masyarakat di Dusun Kerujuk Desa Menggala di dominasi oleh tingkat partisipasi dengan kategori rendah sebanyak 18 responden atau $41,86 \%$ dari keseluruhan responden. Rendahnya partisipasi masyarakat dikarenakan mayoritas masyarakat memiliki partisipasi yang rendah pada kegiatan sosialisasi program ekowisata dan kegiatan identifikasi masalah. Diketahui bahwa rendahnya partisipasi pada kegiatan sosialisasi akibat sistem kebijakan topdown yang diterapkan oleh stakeholder Dusun Kerujuk yang dimana kebijakan topdown tersebut mempengaruhi keterlibatan masyarakat dalam mengambil keputusan.

Rendahnya partisipasi pada tahap perencanaan ini karena rendahnya keterlibatan dan kurang aktif masyarakat dalam menentukan rencana program ekowisata. Hal ini selaras dengan penelitian yang dilakukan Mone (2015), dimana hasil penelitian tersebut menunjukkan dalam setiap rancangan keputusan program desa wisata hanya diputuskan atau disusun oleh pengurus kelompok sadar wisata sangat jarang diketahui dan dikerjakan secara bersama dengan masyarakat setempat karena adanya keterbatasan kekuasan dalam mengambil keputusan yang diserahkan hanya kepada stakeholder.

\section{Partisipasi Masyarakat Ditahap Pelaksanaan}

Tahap pelaksanaan merupakan bentuk implementasi dari perencanaan yang telah disepakati. Tingkat partisipasi masyarakat pada tahap pelaksanaan merupakan cara untuk mengetahui sejauh mana keterlibatan masyarakat dalam membantu membangun program ekowisata kerujuk.

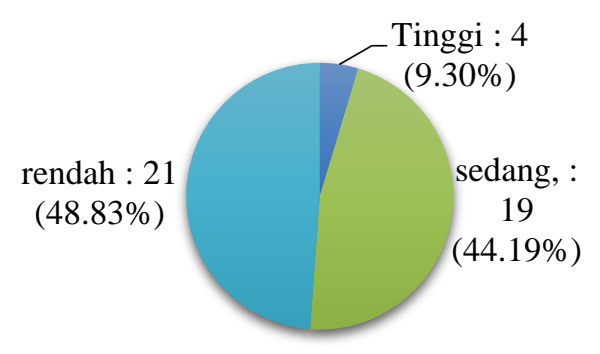

Gambar 3. Jumlah Tingkat Partisipasi Tahap Pelaksanaan

Gambar di atas menunjukkan bahwa, tingkat partisipasi masyarakat di dominasi oleh tingkat partisipasi dengan kategori rendah sebanyak 21 responden atau $48,83 \%$ dari keseluruhan responden. Rendahnya partisipasi masyarakat dikarenakan keterlibatannya dalam pembangunan dan pengelolaan fasilitas ekowisata sangat rendah, pemberian sumbangan materi dan pikiran juga masih sangat kurang, dan keterlibatannya dalam program wisata juga sangat rendah. 
Salah ialah akibat gampa yang terjadi tahun 2018 yang menyebabkan rencana pembangunan pondok-pondok wisata tidak berjalan lancar dan beberapa fasilitas wisata rusak dan tidak terawat dan selain itu tidak ada outlet sovenir dan modal yang dimiliki masyarakat tidak ada untuk melaksanakan program tersebut.

Tingkat partisipasi pada tahap pelaksanaan berada pada kategori rendah karena kurangnya implementasi tentang perencanaan partisipatif di ekowisata kerujuk. Kurangnya implementasi masyarakat ini karena masih kurangnya proses pendekatan, penyebaran informasi dan penyelesaian masalah internal oleh stakeholder. Sehingga hanya masyarakat dan kelompok kerja yang terlibat secara formal yang cenderung berpartisipasi di tahap pelaksanaan ini.

Hal ini tidak selaras dengan penelitian yang dilakukan oleh Apriliani (2017) di Desa Bendungan, tingginya tingkat partisipasi masyarakat karena pelaksanaan kegiatan program pengembangan Desa Wisata di Desa Bendungan dilaksanakan pada hari libur yaitu sabtu dan minggu secara rutin dan informasi yang disebarkan ke masyarakat dalam bentuk pesan berantai. Kemudian beberapa responden yang partisipasinya rendah di tahap pelaksanaan pada penelitian tersebut dikarenakan bekerja di luar daerah, sehingga tidak dapat berkontribusi dalam tahap pelaksanaan tersebut. Berbeda dengan sistem yang diterapkan di Dusun Kerujuk yang tidak terjadwal, sehingga menjadi hal yang wajar apabila masyarakat tidak berpartisipasi karena tidak mengetahui informasi.

\section{Partisipasi Masyarakat Ditahap Pemanfaatan Hasil Ekowisata}

Upaya yang telah dilaksanakan masyarakat dalam mewujudkan Dusun Kerujuk Desa Menggala menjadi ekowisata, tentu memberikan manfaat baik secara langsung maupun tidak langsung. Sejak tahun 2016 masyarakat memanfaatkan hasil dari program ekowisata ini berupa sarana dan prasarana yang sebelumnya tidak ada di Dusun Kerujuk. Beberapa manfaat yang dirasakan oleh masyarakat yaitu kemudahan akses untuk keluar masuk desa karena sejak adanya ekowisata kerujuk, terbangun akses jalan raya beraspal dan jembatan penghubung dusun kerujuk.

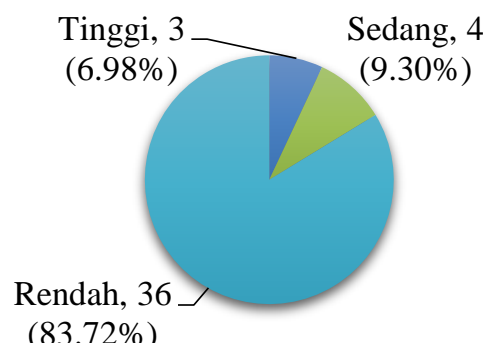

$(83.72 \%)$

Gambar 4. Jumlah Tingkat Partisipasi Tahap Pemanfaatan Hasil

Berdasarkan Gambar 4 mayoritas masyarakat memiliki tingkat partisipasi yang rendah sebanyak $83,72 \%$ pada tahap pemanfaatan hasil. Tingkat partisipasi rendah disebabkan oleh belum meratanya manfaat yang dirasakan oleh masyarakat dari hasil adanya program ekowisata terutama dari sektor perekonomian. Diketahui bahwa ekowisata kerujuk belum dapat menjadi sumber pendapatan masyarakat setempat. Hanya sebagian kecil dari masyarakat yang merasakan manfaat dari segi ekonomi yaitu hanya sebagian masyarakat yang memiliki lahan yang digunakan sebagai destinasi wisata. Namun, secara keseluruhan masyarakat telah merasakan manfaat lain dari adanya ekoiwsata ini 
seperti akses jalan raya, jalan rabat beton di hutan, dan jembatan yang iconic menjadi wujud nyata hasil pembangunan Ekowisata Kerujuk yang menjadi penghubung mobilitas masyarakat setempat. Dengan manfaat yang dirasakan oleh masyarakat dapat mendorong tumbuhnya inovasi serta perbaikan tata nilai di masyarakat setempat.

Tingkat partisipasi pada tahap pemanfaatan hasil berada pada kategori rendah akibat belum meratanya manfaat yang dirasakan oleh masyarakat terutama dalam segi ekonomi. Sebagian besar responden diketahui merasakan manfaat dari segi infrastruktur yang ada setelah adanya Ekowisata Kerujuk. Penelitian ini tidak selaras dengan hasil penelitian Kamilah (2019) tentang Stok Modal Sosial dan Tingkat Partisipasi Dalam Pengembangan Pariwisata Berbasis Masyarakat yang diketahii bahwa $80 \%$ responden mendapatkan manfaat baik dari segi materi maupun non-materi. Dalam penelitian tersebut diketahui bahwa responden berpartisipasi tinggi dalam tahap pelaksanaannya, sehingga implikasinya terhadap menikmati hasil dapat dirasakan secara merata. Perbedaan yang mencolok pada penelitian tersebut terdapat pada implementasi di tahap pemanfaatan hasil dimana masyarakat memiliki hak bebas untuk membuat penginapan, warung makan atau kedai di area wisata tersebut berbeda dengan yang ada di Ekowisata Kerujuk harus tergabung dalam pengelola wisata untuk dapat berjualan dan sebagainya. Dimana diketahui adalah sebagian besar masyarakat yang dapat berjualan adalah kelompok kerja yang berkerjasama dengan pengelola Ekowisata Kerujuk.

\section{Partisipasi Masyarakat Ditahap Pemanfaatan Evaluasi}

Evaluasi atau peninjauan kembali terkait perkembangan pembangunan program ekowisata untuk melihat bagaimana pelaksanaan yang sudah berjalan, apakah sudah sesuai dengan sasaran, apakah sesuai dengan tujuan yang dihharapkan dengan keadaan saat ini, dan mencari solusi-solusi terkait kendalakendala yang menghambat jalanya pembangunan tersebut. Rapat tahap evaluasi pada pengembangan ekowisata kerujuk telah dilaksanakan beberapa kali dan dihadiri oleh masyarakat serta pihak-pihak terkait seperti, Pokdarwis, fasilitator dewa wisata dari kementerian, pemerintah desa dan lainnya.

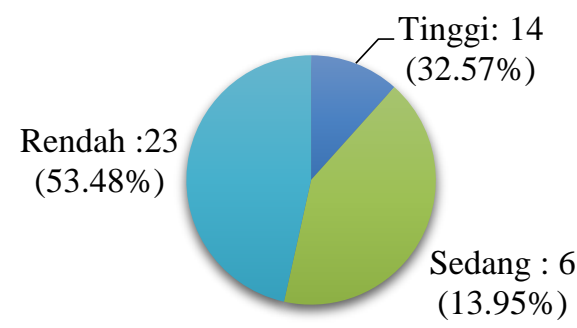

Gambar 5. Jumlah Tingkat Partisipasi Tahap Evaluasi

Gambar 5 menunjukkan bahwa, mayoritas tingkat partisipasi masyarakat pada tahap evaluasi memiliki partisipasi yang rendah sebanyak 23 responden atau $53,48 \%$ dari keseluruhan responden. Rendahnya partisipasi masyarakat pada tahap evaluasi ini karena tidak terlibat dalam menentukan keputusan rencana tindak lanjut serta sangat pasif dalam kegiatan evaluasi. Masyarakat menyatakan bahwa, hanya pemangku kepentingan saja yang memberikan saran serta kebijakannya, masyararakat hanya ikut serta saja dalam keputusan yang ditetapkan kedepannya. 
Penelitian ini selaras dengan hasil penelitian yang diperoleh Dwita (2019) di Desa Nagrog, bahwa di tahap evaluasi masyarakat yang dilibatkan hanya perwakilan saja. Karena dalam penyusunan dan penyampaian laporan hasil pencapaian hanya dilakukan oleh pendamping lokal, fasilitator dan beberapa pihak terkait. Dengan demikian, informasi tentang pelaksanaan evaluasi tersebut bersifat tertutup atau tidak ada transparansi di masyarakat. Hal tersebut juga selaras dengan sistem yang terjadi di Dusun Kerujuk pada tahap evaluasi, dimana hanya pemangku kepentingan saja yang mengetahui hasil, saran dan rencana tidak lanjut yang disampaikan.

\section{Analisis Faktor- faktor Yang Berhubungan Dengan Tingkat Partisipasi Masyarakat}

Penggunaan uji korelasi rank spearman menuurt Sugiyono (2016), untuk menguji hipotesis apabila data berbentuk ordinal, maka dapat menggunakan uji korelsi Rank Spearman.

Tabel 5. Nilai Koefisien Korelasi Output SPSS

\begin{tabular}{ccc}
\hline No & Nilai Koefisien & Tingkat Hubungan \\
\hline 1 & $0,00-0,25$ & Hubungan Sangat Lemah \\
2 & $0,26-0,50$ & Hubungan Lemah \\
3 & $0,51-0,75$ & Hubungan Kuat \\
4 & $0,76-0,99$ & Hubungan Sangat Kuat \\
5 & 1,00 & Hubungan Sempurna \\
\hline
\end{tabular}

Tabel 6. Hasil Uji Analisis Faktor-faktor yang Berhubungan dengan Partisipasi Masyarakat

\begin{tabular}{lccc}
\hline \multirow{2}{*}{\multicolumn{1}{c}{ Hubungan }} & \multicolumn{3}{c}{ Spearman rho } \\
\cline { 2 - 4 } & $\begin{array}{c}\text { Correlation } \\
\text { Coefficient }\end{array}$ & Sig.(2-tailed) & $\mathrm{N}$ \\
\hline Umur & 0.481 & 0.001 & 43 \\
Pendidikan Formal & 0.258 & 0.095 & 43 \\
Pendidikan Non Formal & 0.897 & 0.000 & 43 \\
Pekerjaan & 0.361 & 0.01 & 43 \\
Pendapatan & 0.639 & 0.000 & 43 \\
Lama Tinggal & 0.505 & 0.001 & 43 \\
\hline
\end{tabular}

Sumber : Data Primer diolah (2021)

Berdasarkan hasil analisis faktor-faktor yang berhubungan dengan partisipasi masyarakat pada Tabel 6, dapat diketahui bahwa hampir seluruh faktor hubungan berpengaruh terhadap partisipasi masyarakat kecuali tingkat pendidikan formal. Adapun penjelasan masing-masing faktor hubungan yaitu sebagai berikut. 1. Umur

Hasil pengolahan data primer diatas, umur memiliki tingkat koreasi hubungan yang lemah yaitu 0.481. Nilai sig. (2-tailed) $0.001<(\alpha) 0.01$ maka hipotesis H0 di tolak. Artinya bahwa antara umur dan partisipasi masyarakat Dusun Kerujuk memiliki korelasi hubungan yang signifikan dan berada hubungan yang cukup kuat.

2. Pendidikan Formal 
Diketahui uji korelasi antara pendidikan formal dengan partisipasi diketahui bernilai 0.258 yang menunjukkan bahwa tingkat keeretan hubungan yang sangat lemah. Nilai sig. (2-tailed) 0,095 $>(\alpha) 0,01$ maka H0 diterima. Artinya tidak ada hubungan antara 81endidikan formal seseorang dengan tingkat partisipasinya dalam berkontribusi untuk pengembangan ekowisata kerujuk.

2. Pendidikan non formal

Diketahui uji korelasi antara Pendidikan non formal dengan partisipasi bernilai 0.897 yang menunjukkan bahwa tingkat keeratan hubungan yang kuat. Nilai sig. (2-tailed) yaitu $0.000<(\alpha) 0.01$, maka H0 ditolak dan berarti terdapat hubungan antara 81endidikan formal seseorang dengan tingkat partisipasinya. Hubungan yang sangat kuat ini sangat signifikan saling berhubungan positif.

3. Pekerjaan

Diketahui uji korelasi antara pekerjaan seseorang dengan partisipasi dengan bernilai 0.361 yang menunjukkan hubungan bahwa tingkat keeratan hubungan yang lemah. Nilai sig. (2-tailed) yaitu $0,001>(\alpha) 0.01$, maka H0 ditolak, artinya terdapat hubungan pekerjaan seseorang dengan tingkat partisipasi yang dikontribusikan.

4. Pendapatan

Diketahui uji korelasi antara tingkat pendapatan seseorang dengan partisipasi bernilai 0.639 yang menunjukkan keeratan hubungan yang kuat. Nilai sig. (2-tailed) yang diperoleh senilai $0.000<(\alpha) 0.01$, maka H0 ditolak. Artinya terdapat hubungan antara pendapatan seseorang dengan tingkat partisipasi.

5. Lama Tinggal

Diketahui uji korelasi antara lama tinggalnya seseorang dengan partisipasi bernilai 0.505 yang menunjukkan keeratan hubungan yang kuat. Nilai sig. (2tailed) yang diperoleh senilai $0.001<(\alpha) 0.01$, maka H0 ditolak. Artinya terdapat hubungan antara lama tinggal seseorang dengan tingkat partisipasi.

Marysya \& Amanah (2018) dalam penelitiannya tentang Tingkat Partisipasi Masyarakat Dalam Pengelolaan Wisata Berbasis Potensi Desa Di Kampung Wisata Situ Gede Bogor menggunakan metode analisis yang selaras dengan penelitian ini untuk mengukur keeratan hubungan dengan tingkat partisipasi seseorang yaitu uji korelasi rank spearman. Dalam penelitiannya diketahui bahwa umur, pekerjaan, pendapatan dan lama tinggal berhubungan dengan tingkat partisipasi seseorang. Hal ini memiliki keselarasan di hasil penelitian di Dusun Kerujuk bahwa, umur, pekerjaan, pendapat dan lama tinggal memiliki hubungan dengan tingkat partisipasi seseorang.

\section{Analisis Strategi Peningkatan Partisipasi Masyarakat}

Analisis SWOT ini merupakan langkah analisis yang digunakan untuk mencari alternatif strategi yang didapatkan dari faktor-faktor internal dan eksternal. Matriks SWOT digunakan sebagai alat pencocokan yang penting dalam mengembangkan jenis starategi seperti startegi SO (strength - opportunity), strategi WO (weakness - opportunity), strategi ST (strength - threat), dan strategi WT (weakness - threat). 
Tabel 7. Hasil Perhitungan IFAS

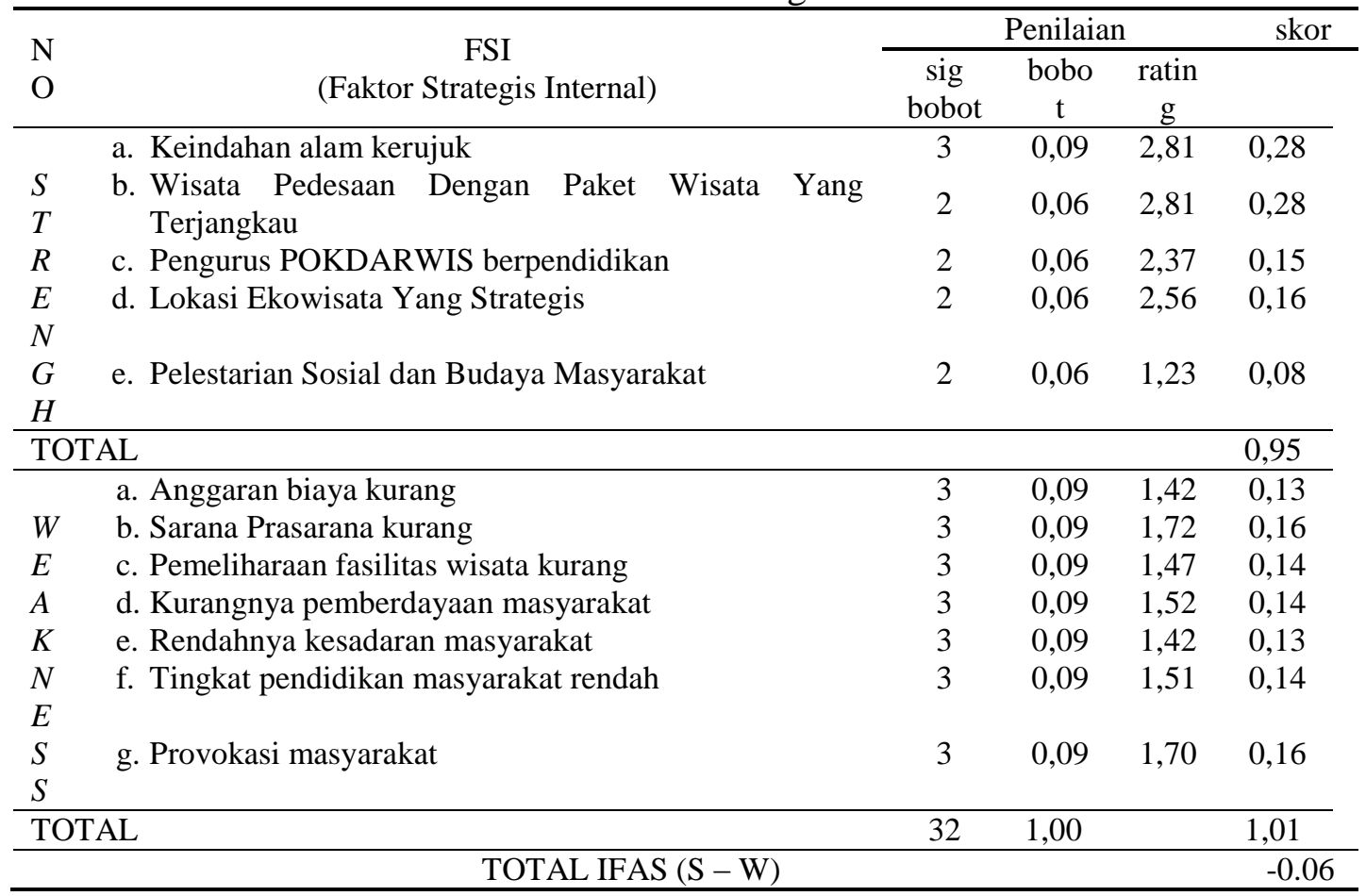

Sumber : Data Primer diolah (2021)

Berdasarkan pada tabel 7. maka total IFAS yang didapatkan sebesar -0.06. Nilai IFAS didapatkan dari selisih total skor strength dan skor weakness, yaitu $0.95-1.01,=-0.06$. Hasil yang diperoleh ini menjadi titik koordinat " $\mathrm{x}$ " untuk kuadran starategi SWOT dapat dilihat pada gambar 8.

Tabel 8. Hasil Perhitungan EFAS

\begin{tabular}{|c|c|c|c|c|c|}
\hline \multirow[t]{2}{*}{ NO } & \multirow{2}{*}{$\begin{array}{c}\text { FSE } \\
\text { (Faktor Strategis Eksternal) }\end{array}$} & \multicolumn{3}{|c|}{ Penilaian } & \multirow[t]{2}{*}{ Skor } \\
\hline & & $\begin{array}{c}\text { Sig } \\
\text { Bobot }\end{array}$ & bobot & rating & \\
\hline \multirow{6}{*}{$\begin{array}{l}\text { OPPOR } \\
\text { TUNITY }\end{array}$} & a. Bantuan dana pemerintah & 3 & 0,13 & 2,95 & 0,38 \\
\hline & b. Tidak ada persaingan desa wisata lainnya & 2 & 0,09 & 2,80 & 0,24 \\
\hline & c. Adanya kerjasama dengan pemerintah dan & 3 & 0,13 & 2,88 & 0,38 \\
\hline & lembaga pendidikan & & & & \\
\hline & d. Penyerapan tenaga kerja pelaku wisata & 3 & 0,13 & 2,88 & 0,38 \\
\hline & $\begin{array}{l}\text { e. Promosi wisata dari wistawan dan website } \\
\text { wisata }\end{array}$ & 3 & 0,13 & 2,86 & 0,37 \\
\hline \multirow[t]{2}{*}{ TOTAL } & & & & & 0,99 \\
\hline & $\begin{array}{l}\text { a. Ancaman persaingan pasar (pembangunan } \\
\text { hotel, rumah makan, pusat oleh-oleh, dll.) }\end{array}$ & 2 & 0,09 & 1,23 & 0,11 \\
\hline $\mathrm{H}$ & b. Bencana alam & 3 & 0,13 & 1,05 & 0,14 \\
\hline $\mathrm{R}$ & c. Kurangnya kesadaran pengunjung menjaga & 2 & 0,09 & 2,35 & 0,20 \\
\hline $\mathrm{E}$ & fasilitas/objek wisata & & & & \\
\hline A & d. Semakin rendahnya minat wisatawan & 2 & 0,09 & 1,21 & 0,11 \\
\hline $\mathrm{T}$ & $\begin{array}{l}\text { berkunjung karena hilangnya citra ekowisata } \\
\text { kerujuk }\end{array}$ & & & & \\
\hline \multirow[t]{2}{*}{ Total } & & 23 & 1,00 & & 0,55 \\
\hline & TOTAL EFAS (O-T) & & & & 0,44 \\
\hline
\end{tabular}

Sumber : Data Primer diolah Tahun 2021

Khairunnisa, A., Karyadi, L.W., dan Sayuti,R.H. 
Berdasarkan pada tabel 8, maka total EFAS yang didapatkan sebesar 0.44. Nilai EFAS didapatkan dari pengurangan antara total skor opportunity dan total skor threat, yaitu 0,99 - 0.55, maka didapatkan hasil sebesar 0,44. Hasil yang diperoleh ini menjadi titik koordinat " $y$ " untuk kuadran starategi SWOT dapat dilihat pada gambar 6. Dengan demikian didapatkan titik koordinat x (-0.06) dan y (0.44), dan dihasilkan strategi terletak pada kuadran 3 yang berarti strategi yang dikembangkan yaitu WO (weakness - opportunity).

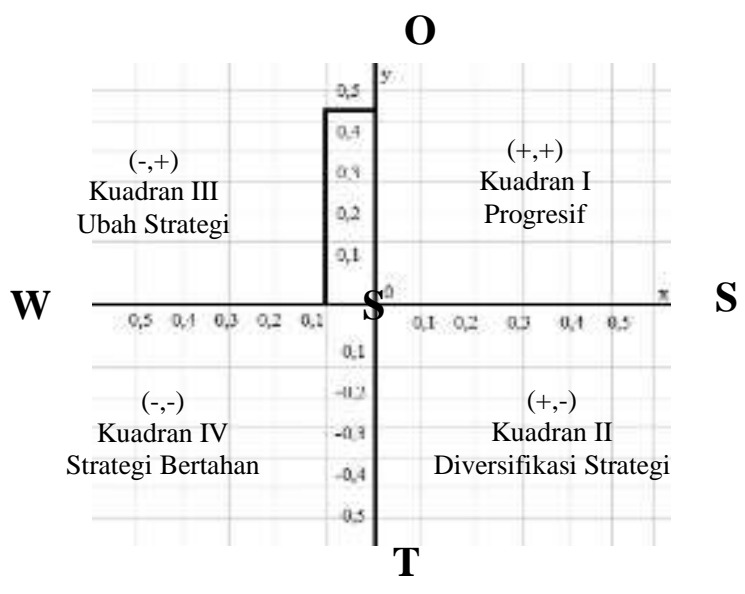

Gambar 6. Matriks Kuadran SWOT

Strategi WO atau (weakness-opportunity) merupakan strategi yang diterapkan berdasarkan pemanfaatan peluang yang ada dengan cara meminimalkan kelemahan yang ada. Strategi $W O$ bertujuan untuk memperbaiki kelemahan internal dengan memanfaatkan peluang eksternal. Dari hasil analisis IFAS dan EFAS maka diketahui bahwa strategi $W O$ yang terpilih menjadi strategi untuk meningkatkan partisipasi masyarakat dalam mengembangkan kawasan ekowisata kerujuk. Strategi $W O$ ini dapat menjadi solusi melalui penerapan ide ide baru sebagai penguatan opportunity dengan strength yang ada. Kelemahan yang ada yaitu kurangnya anggaran biaya untuk mengembangkan ekowisata kerujuk dan kurangnya pelibatan masyarakat secara menyeluruh oleh pengelola ekowisata. Kelemahan ini dapat diminimalisir dengan memanfaatkan pihak eksternal sebagai sumber dana dan juga mengadakan upaya pelatihan bagi masyarakat keseluruhan dengan beberapa instansi terkait.

Berdasarkan gambar 6, dapat diketahui bahwa strategi partisipasi masyarakat berada pada posisi di antara sumbu weakness dan opportunity yaitu kuadran 3 atau mengembangkan strategi peningkatan partisipasi dengan starategi WO (weakness - opportunity). Strategi WO yang dapat diterapkan oleh Pokdarwis dalam hal ini sebagai pengelola ekowisata kerujuk, yaitu:

a. Mengupayakan Peluang Bantuan Anggaran Dana Ekowisata

Peluang yang dimiliki untuk dapat meningkatkan partisipasi masyarakat tentu dengan menambahkan anggaran untuk dapat mengembangkan fasilitas atau infrastruktur di ekowisata kerujuk. Dengan jumlah dana anggaran yang cukup, tentu partisipasi masyarakat untuk dapat menambahkan fasilitas baru lainnya atau merawat dan mengelola fasilitas ekowisata yang sudah ada sehingga dapat dimanfaatkan kembali. 
b. Mengupayakan Peluang Kerjasama Dengan Pemerintah dan Lembaga Pendidikan

Sumberdaya manusia merupakan aset yang memegang peran penting dalam mengembangkan kawasan ekowisata yang berbasis masyarakat. Peningkatan kualitas sumberdaya manusia yang memiliki sikap, wawasan, kemampuan, keahlian serta keterampilan dalam sektor wisata memerlukan kerjasama dengan lembaga pendidikan atau pemerintah dalam upaya meningkatkan kualitas sumberdaya manusia. Hal ini dapat memicu tingkat partisipasi karena masih banyak masyarakat yang pendidikannya rendah sehingga kurang mampu untuk berpartisipasi seperti memberikan pendapat atau pandangan mengenai kemajuan ekowisata kerujuk.

Strategi yang dapat diupayakan untuk meningkatkan partisipasi masyarakat dengan cara meningkatkan kualitas sumberdaya manusia sehingga mampu secara menyeluruh untuk dapat menerima inovasi. Dengan adanya peluang kerjasama dengan pihak eksternal seperti pemerintah atau lembaga pendidikan untuk mengedukasi masyarakat. Kerjasama dengan pemerintah atau lembaga pendidikan seperti Perguruan Tinggi Negeri seperti Universitas Mataram, Kementerian Pariwisata atau Dinas Pariwisata, Kementerian Desa Pembangunan Daerah Tertinggal dan Trasmigrasi, Dinas Pertanian, dan lainnya dapat dilakukan kerjasama untuk pengabdian atau pembinaan dalam menerapkan konsep desa wisata berbasis masyarakat. Proses pendekatan yang masih kurang dapat diatasi oleh pengelola ekowisata kerujuk ini dapat diatasi oleh pihak eksternal dengan mengadakan beberapa program pengembangan diri yang mencakup proses dalam menganalisa dan membuat kebijakan bersama, manajemen, pelatihan, sosialiasasi dan lainnya.

c. Meningkatkan Promosi Wisata Kembali

Setelah cukup lama menutup kunjungan wisata akibat pandemi Covid-19, strategi yang dapat dilakukan setelah melakukan rejuvenation atau peremajaan kembali rogram-program wisata adalah melakukan re-launching program wisata yang berbeda dari sebelumnya tanpa meninggalkan citra asli Ekowisata Kerujuk. Melakukan evaluasi dari pelaksanaan program ekowisata sebelumnya dengan lebih banyak melibatkan peran serta masyarakat setempat. Re-launching tidak terlepas dari promosi wisata yang akan dilakukan. Maka diperlukan beberapa strategi untuk melakukan promosi wisata kembali seperti, membuat event-event yang dapat memberikan pengaruh seperti Gubernur Nusa Tenggara Barat, selebgram, blogger atau vlogger dan lainnya.

Promosi wisata ini bertujuan untuk memberikan informasi kepada masyarakat luas bahwa Ekowisata Kerujuk telah kembali membuka program wisata dengan cover berbeda dari sebelumnya. Melalui beberapa postingan di facebook, instagram, blog dan lainnya yang dapat mengundang masyarakat untuk mau berkunjung ke Ekowisata Kerujuk. Tentu hal tersebut tidak lepas dari upaya masyarakat Dusun Kerujuk untuk melakukan pembaharuan inovasi pada objekobjek wisata yang ada. Hasil ini sesuai dengan hasil penelitian Ariani \& Nursan, (2017), yang menemukan bahwa untuk meraih peluang dengan cara meminimalisir kelemahan. Desa Wisata harus sering dipromosikan melalui berbagai media baik di media cetak maupun elektronik oleh Pemerintah Daerah.

Selain itu, penelitian ini juga sesuai dengan temuan pada penelitian Hidayat (2016) dalam penelitiannya tentang Strategi Pengembangan Ekowisata di Desa 
Kinarum Kabupaten Tabalong menggunakan analisis SWOT. Diketahui dari hasil penelitiannya, strategi yang diperoleh sama yaitu strategi WO (waekness dan opportunity). Dalam penelitiannya diketahui bahwa sumberdaya lokal atau masyarakat setempat belum berpartisipasi secara maksimal dalam mengembangkan budaya Desa Kinarum. Sehingga direkomendasikan adanya bantuan pihak eksternal untuk melakukan kerjasama dalam meningkatkan kualitas sumberdaya lokal yang dapat berdaya saing dengan sistem kebijakan yang berbasis masyarakat lokal.

\section{KESIMPULAN DAN SARAN}

\section{Kesimpulan}

Berdasarkan hasil dan pembahasan serta mengacu pada tujuan penelitian, maka dapat ditarik kesimpulan sebagai berikut :

1) Tingkat partisipasi masyarakat dalam pengembangkan ekowisata kerujuk secara keseluruhan maupun pada setiap tahap (perencanaan, pelaksanaan, pemanfaatan hasil, dan evaluasi) berada dalam kategori rendah.

2) Faktor - faktor yang berhubungan dengan partisipasi masyarakat dalam mengembangkan ekowisata kerujuk secara berturut turut adalah pendidikan non formal, pendapatan, lama tinggal, dan umur. Sedangkan pendidikan formal dan pekerjaan cenderung tidak memiliki hubungan dan hubungan lemah.

3) Strategi yang dapat diterapkan untuk meningkatkan partisipasi masyarakat dalam upaya pengembangkan ekowisata kerujuk adalah strategi WO (weaknes - opportunity) atau strategi untuk meminilisir kelemahan internal (weakness) dengan memanfaatkan peluang ekternal (opportunity) yang ada seperti peluang untuk mendapatkan bantuan dana dan peningkatan kualitas sumberdaya masyarakat.

\section{Saran}

Berdasarkan kesimpulan di atas maka diajukan saran sebagai berikut :

1) Dalam rangka mengembangkan ekowisata kerujuk diharapkan kepada masyarakat lokal agar dapat melibatkan diri dan meningkatkan inisiatifnya dalam upaya membangun kualitas sumberdaya manusia yang kompetitif, kreatif, dan inovatif.

2) Kelompok Pokdarwis Kerujuk Lestari yang memiliki tanggung jawab sebagai pengelola Ekowisata Kerujuk agar dapat mengelola dan merawat fasilitas yang sudah ada agar tidak rusak karena tidak pernah dipakai. Serta melibatkan masyarakat lebih banyak lagi dalam kegiatan-kegiatan gotong royong untuk upaya membangun kembali ekowisata kerujuk.

3) Diharapkan kepada pemerintah untuk dapat memberikan pelatihan dan pembinaan secara intensif untuk meningkatkan kualitas sumberdaya manusia sehingga mampu mengembangkan inovasi dan mengoptimalkan potensi ekowisata. 


\section{DAFTAR PUSTAKA}

Ariani, Z., \& Nursan, M. (2017). Strategi Pengembangan Desa Mantar Sebagai Kawasan Desa Wisata di Kabupaten Sumbawa Barat. Biologi Tropis, 17(2), $58-68$.

Apriliani, T. (2017). Tingkat Partisipasi Masyarakat Dan Efektivitasprogram Ecovillage Desa Bendungan, Kecamatan Ciawi, Kabupaten Bogor. KPM Kearsipan Fakultas Ekologi Manusia: Institut Pertanian Bogor.

BPS NTB. (2019). NTB Dalam Angka 2019. Mataram: Badan Pusat Statistik Provinsi NTB.

Dinas Pariwisata dan Kebudayaan Kabupaten Nias. (2009). Ekowisata: Panduan Dasar Pelaksanaan. Dinas Pariwisata dan Kebudayaan Kabupaten Nias: Kabupaten Nias Selatan.

Dwita, R. (2019). Analisis Hubungan Tingkat Partisipasi Dantingkat Keberdayaan Masyarakat Dalamprogram Pengembangan Masyarakat Berkelanjutan. KPM kearsipan Fakultas Ekologi Manusia: Institut Pertanian Bogor.

Hidayat, S. 2016. Strategi Pengembangan Ekowisata di Desa Kinarum Kabupaten Tabalong. Jurnal Hutan Tropis, 4 (3), 282-292.

Kamilah, F. 2019. Stok Modal Sosial dan Tingkat Partisipasi dalam Pengembangan Pariwisata Berbasis Masyarakat [Skripsi]. Bogor: Institut Pertanian Bogor.

Manggala, Y. \& Mustam, M. (2017). Analisis faktor-faktor dalam partisipasi masyarakat pada pembangunan Desa Wisata Genting Kabupaten Semarang. Journal of Public Policy and Management Review, 6(2), 296-309.

Marysya, P., \& Amanah, S. (2018). Tingkat partisipasi masyarakat dalam pengelolaan wisata berbasis potensi desa di Kampung Wisata Situ Gede Bogor. Jurnal SKPM, 2(1), 59-70.

Nazir, M. (2014). Metode Penelitian. Bogor: Ghalia Indonesia.

Sahawi, M.E. 2015. Partisipasi Masyarakat Dalam Pengembangan Desa Wisata Dan Dampaknya Terhadap Peningkatan Ekonomi Masyarakat. KPM 403 kearsipan Fakultas Ekologi Manusia: Institut Pertanian Bogor.

Sugiyono. (2013). Metode Penelitian Kuantitatif Kualitatif dan R\&D. Bandung: Alfabeta.

Zuhriana, D. 2013. Peningkatan peluang kerja bagi masyarakat lokal melalui pengembangan ekowisata di Taman Nasional Gunung Ciremai. Media Konservasi, 18(1), 28-39. https://doi.org/10.29244/medkon.18.1.\%25p 